Al Qalam: Jurnal IImiah Keagamaan dan Kemasyarakatan https://jurnal.stiq-amuntai.ac.id/index.php/al-qalam

P-ISSN: 1907-4174; E-ISSN: 2621-0681

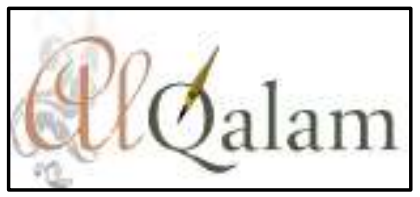

\title{
HOME INDUSTRY SEBAGAI STRATEGI PEMBERDAYAAN USAHA MIKRO DALAM \\ MENINGKATKAN FINANCIAL REVENUES MASYARAKAT
}

\author{
Oleh: \\ Achmad Fawaid ${ }^{1}$, Erwin Fatmala ${ }^{2}$ \\ Dosen Universitas Nurul Jadid, Probolinggo, Indonesia ${ }^{1,2}$ \\ email: fawaidachmad@gmail.com ${ }^{1}$,erwinfatmala@gmail.com²
}

\begin{abstract}
ABSTRAK
Saat ini home industry mulai banyak bermunculan di Negara kita, seperti halnya yang terjadi di beberapa desa. Mereka memulai usaha ini dimulai dengan mengolah dan memanfaatkan hasil perkebunan atau pertanian yang dimiliki. Melihat begitu banyaknya home industry dalam satu daerah menjadi suatu peluang yang sangat baik terhadap ekonomi masyarakat, namun diperlukan adanya upaya untuk melindungi dan mengembangkan usaha ini, salah satunya dengan pemberdayaan. Penelitian ini bertujuan untuk mengetahui home industry kripik singkong Gazal Makmur menjadi suatu strategi pemberdayaan usaha mikro di Dusun Gazal Desa Kotaanyar Kecamatan Kotaanyar Kabupaten Probolinggo, sehingga pendapatan masyarakat disekitar bertambah atau meningkat. Metode yang digunakan dalam penelitian ialah metode kualitatif, sedangkan subjeknya 3 pemilik home industry keripik singkong gazal makmur dikarenakan peneliti menggunakan purposive sampling dengan populasi 7 pemilik home industry. Sedangkan data yang sudah didapatkan dan dijelaskan secara kualitatif dan dalam hasil penelitian menunjukkan bahwa dengan adanya home industry kripik singkong gazal makmur ini menjadi suatu strategi dalam Usaha Mikro dan dapat meningkatkan pendapatan masyarakat.
\end{abstract}

Kata kunci: home industry, pemberdayaan usaha mikro, peningkatan financial 
Achmad Fawaid \& Erwin Fatmala: Home Industri Sebagai Pemberdayaan Usaha Mikro Dalam Meningkatkan Financial Revenues Masyarakat

\begin{abstract}
At this time, home industries are starting to emerge in our country, as is the case in several villages. They started this business by processing and utilizing the results of their plantations or agriculture. Seeing so many home industries in one region becomes a very good apportunity for the economy of the community, but efforts are needed to protect and develop this business, one of which is empowerment. This research aims to find a prosperous home industry of cassava gazal cassava chips into a strategy for empowering micro businesses in Gazal Hamlet, Kotaanyar Village, Kotaanyar Subdistrict, Probolinggo Regency, so that the income of the surrounding community increases or increases. The method used in this study is a qualitative method, while the subject is 3 homeowners of prosperous cassava gazal chips home industry because the researchers used purposive sampling with a population of 7 home industry owners. While the data that has been obtained and explained qualitatively and in the results of the study indicate that with the existence of a prosperous home industry, the prosperous gazal cassava chips has become a strategy in Micro Enterprises and can increase people's income.
\end{abstract}

Keywords: home industry, micro businessempowerment, financial improvement

\title{
PENDAHULUAN
}

Indonesia merupakan negara berkembang yang mana perekonomian menjadi masalah utama yang harus dihadapi oleh negara berkembang, ditambah lagi dengan ekonomi global yang selalu berubahubah membuat negara berkembang harus siap untuk menghadapinya. Saat ini salah satu cara negara Indonesia mengatasi masalah tersebut ialah dengan fokus pada mikro ekonomi, karena makro ekonomi Indonesia dalam beberapa tahun ini selalu mengalami defisit.

Dengan memanfaatkan sumber daya manusia secara optimal serta melestarikan usaha yang mandiri merupakan suatu kegiatan untuk mempercepat perekonomian dan memperkuat pembangunan agar terciptanya keadilan bagi semua masyarakat. Namun masalah ini harus dikerjakan oleh semua pihak dalam artian tanggung jawab bersama antara pihak yang berwenang (pemerintah) dengan masyarakat sekitar, untuk melakukan kerjasama dan kesuksesan bersama, terutama masyarakat 
sebagai pelaku utama dalam pembangunan sedangkan pemerintah mempunyai peran yang besar dalam memberikan pengarahan, memberikan bimbingan, dan memberikan fasilitas sebagai penunjang.

Mikro ekonomi yang diprioritaskan oleh pemerintah saat ini ialah mengembangkan usaha mikro kecil dan menengah, meninjau fakta bahwasanya usaha ini banyak memberikan kontribusi dalam ekonomi nasional. UMKM menjadi sangat baik karena nanti berpotensi pada pergerakan ekonomi masyarakat, juga menjadi sumber pendapatan sebagian masyarakat untuk meningkatkan kesejahteraannya. ${ }^{1}$

UMKM menjadi tempat untuk menciptakan lapangan pekerjaan, selain itu UMKM juga usaha padat karya, yang tidak membutuhkan syaratsyarat tertentu misalnya pendidikan, keterampilan dalam bekerja dan syarat yang lainnya. UMKM memang menjadi peran yang penting untuk memperbaiki ekonomi negara kita, baik dalam segi menciptakan lapangan pekerjaan, jumlah usaha ataupun dari segi pertumbuhan ekonomi nasional. ${ }^{2}$

Suryana mengemukakan bahwasanya pembangunan ekonomi suatu daerah dikatakan berhasil karena dipengaruhi oleh beberapa faktor, diantaranya; sumber daya manusia (penyediaan karyawan, pembelajaran, kedisiplinan dan motivasi), sumber daya alam, pembentukan modal, teknologi dan kewirausahaan. Selain itu terdapat komponen lain yang dapat mempengaruhi seperti tumbuhnya perekonomian di masyarakat dan usaha di daerah tersebut. ${ }^{3}$

Kebijakan ini dapat dikatakan sebagai langkah tepat yang dilakukan oleh pemerintah untuk membangkitkan perekonomian bangsa ini. Seperti halnya pada tahun 1997 saat Indonesia mengalami krisis, usaha mikro ini berperan strategis untuk mengatasi dengan mampu memberikan kontribusi dalam pertumbuhan ekonomi Negara Indonesia.

Jika kita melirik pada negara-negara maju, baik Cina, Jepang, Jerman dan Negara maju lainnya, usaha mikro dijadikan sebagai tonggak utama dalam perekonomian negara. Kemungkinan yang terjadi ialah

${ }^{1}$ Ariani dan Mohammad Nur Utomo, Kajian Strategi Pengembangan Usaha Mikro Kecil dan Mengengah (UMKM) di Kota Tarakan, Jurnal Organisasi dan Manajemen, Vol. 13 No. 2 Sepetember 2017, (Tanggerang Selatan: LPPM Universitas Terbuka 2017), h. 100

${ }^{2}$ Amin Dwi Ananda dan Dwi Susilowati, Pengembangan Usaha Mikro Kecil dan Menengah (UMKM)Berbasis Industry Kreatif di Kota Malang, Jurnal Ilmu Ekonomi, Vol. 10 No. 10 Tahun 2017, (Malang: Universitas Muhammadiyah Malang 2017), h. 120

${ }^{3}$ Lutfiyah, Pengaruh Pertumbuhan Ekonomidan Usaha Mikro Kecil Menengah (UMKM) Terhadap Pendapatan Asli Daerah (PAD) di Kabupaten Bangkalan, Jurnal Pendidikan dan Ekonomi, Vol. 4 No. 2 Tahun 2016, (Surabaya: Universitas Negeri Surabaya 2016), h. 205 
pemerintahan dari negara-negara tersebut mempunyai kebijakan tersendiri untuk memberikan dukungan sehingga tercipta kondisi yang mana usaha kecil ini menjadi sehat dan kuat.

Memang usaha-usaha kecil ini tidak dapat dilihat dengan kasat mata seperti pada perusahaan besar. Mereka biasanya ada di perumahan, di bangunan dari garasi/dapur rumah, pinggir jalan, mulai dari usaha kuliner, bengkel, pakaian, aksesoris dan kerajinan lainnya. Usaha-usaha ini mempunyai ketahanan yang tinggi dikarenakan mereka tumbuh secara alami.

Negara Indonesia sendiri sudah memiliki peluang yang cukup besar baik dari kekayaan alam dan dari manusia (tenaga kerja), namun peluang itu tidak bisa dijadikan suatu kebanggaan. Faktanya di negara kita masih terdapat kesenjangan ekonomi yang cukup besar, salah satu penyebabnya ialah masih kurangnya pengetahuan (pendidikan) dan keterampilan penduduk desa atau kota untuk menggunakan sumber daya alam yang ada.

Kedua sumber daya memiliki hubungan yang sangat erat untuk mewujudkan suatu perusahaan atau bisnis yang dapat mendongkrak perekonomian, jika sumber daya alam yang kita punya dapat dioperasikan dengan baik oleh sumber daya manusia (human capital) yang terampil, berpendidikan serta mempunyai mental wirausaha. ${ }^{4}$

Pengembangan usaha mikro di negara kita menjadi salah satu pilihan utama untuk membangunan ekonomi nasional. Dikarenakan usaha ini dapat dijadikan sebagai tulang punggung sistem ekonomi kerakyatan seperti pengurangan kesenjangan yang terjadi di masyarakat berkurang, perekonomian dapat berkembang luas dan bisa memberikan kontribusi yang begitu signifikan untuk mempercepat laju perubahan, yaitu meningkatkan ekonomi dan ketahanan ekonomi nasioal. ${ }^{5}$

Usaha mikro cukup stabil dalam menjaga keseimbangan kondisi disaat masa krisis melanda. Karena permodalan yang dibutuhkan dalam usaha ini tidak terlalu banyak, cukup padat karya dan mempunyai segmentasi pasar yang stabil. Secara historis juga, kehadiran industri ini jauh lebih dulu dari pada industri-industri modern, meskipun dalam segi

${ }^{4}$ Dini Rochdiani, et al., Manajemen Usaha Home Industry Desa Sindangsari Kecamatan Sukasari Kabupaten Sumedang, Jurnal Aplikasi Iptek Untuk Masyarakat, Vol. 7 No. 1 Maret 2018, (Jawa Barat: Direktorat Sumber Daya Akademik Universitas Padjadjaran 2018), h. 51

${ }^{5}$ Saifuddin Zuhri, Analisis Pengembangan Usaha Kecil Home Industry Sangkar Ayam Dalam Rangka Pengentasan Kemiskinan, Jurnal Manajemen Akuntansi, Vol. 2 No. 3 Desember 2013, (Malang: Universitas Widyagama 2013), h. 48 
penghasilan masih terbilang rendah, akan tetapi eksistensinya tidak dapat dihilangkan dalam kesuksesan perekonomian. Suatu home industry adalah awal dari memulai usaha dalam bidang apapun. Industri yang besar dan bagus pasti bermula dari usaha mikro.

Saat ini beberapa usaha mulai bermunculan di Indonesia khususnya home industry di desa-desa kecil. Home industry sebagai bentuk kegiatan dalam usaha dan sebagai bentuk ekonomi rakyat yang mempunyai potensi untuk mengembangkan ekonomi kerakyatan, serta memiliki dampak dalam meningkatkan perekonomian nasional dengan tidak mengesampingkan demokrasi ekonomi Indonesia.

Industri ini juga termasuk salah satu unsure penting dalam mengembangkan ekonomi lokal. Dari segi tenaga kerja, dalam industri ini dimasuki oleh tenaga kerja pedesaan yang secara umum tidak mengharuskan untuk berpendidikan tinggi tetapi memerlukan kecermatan, keterampilan, ketelitian, ketekunan dan faktor penunjang lainnya.

Dalam segi pendapatan, industri adalah sumber pendapatan tambahan keluarga dan sebagai penunjang kegiatan pertanian yang pada dasarnya adalah mata pencaharian masyarakat pedesaan. Karena pentingnya peran industri dalam pedesaan diharapkan kegiatan ini dapat meningkatkan kesejahteraan masyarakat desa.

Home industry juga dijadikan media oleh sebagian masyarakat yang dapat berkembang serta tumbuh sendiri dengan kontribusi yang besar dan cara yang startegis untuk pembangunan ekonomi. Secara umum dapat dikatakan bahwasanya industri rumahan ini termasuk sektor informal, memproduksikan barangnya secara khas dan unik, berkaitan dengan kearifan lokal, sumber daya baik alam dan manusianya juga dari setempat, modal kecil dan tenaga kerja yang benar-benar harus profesional.

Melihat dari arus globalisasi dan tigginya persaingan membuat semua usaha baik itu kecil, menengah dan besar harus mampu menghadapi keadaan ini. Hal ini dapat kita atasi dengan memberdayakan usaha yang dimiliki agar memberikan perubahan yang lebih baik kedepannya, sehingga dapat bersaing dengan produk-produk hasil lainnya.

\section{KAJIAN PUSTAKA}

Secara bahasa home adalah rumah, tempat untuk menetap, atau kampung halaman dan industry sendiri ialah kerjaninan atau produk yang dijual dari usaha ynag dilakukan. Lebih ringkasnya home industry adalah usaha pribadi yang dilakukan di rumahn untuk menghasilkan barang baru. ${ }^{6}$ Selain itu dikenal dengan perusahaan yang kecil karena kegiatannya berpusat dirumah atau usaha rumah tangga karena dikelola oleh

${ }^{6}$ Saifuddin Zuhri, Analisis Pengembangan.......", h. 48 
keluarga.Serta memiliki tujuan untuk mendapatkan laba sebagai cerminan dari pertumbuhan di hartanya. ${ }^{7}$

Dalam Undang-Undang No. 3 Tahun 2014 Pasal 1 dijelaskan bahwasanya industri merupakan usaha atau kegiatan mengelola barang mentah atau setengah jadi menjadi suatu produk sehingga menghasilkan laba/keuntungan dan yang dihasilkan bukan hanya berupa barang tapi juga berupa jasa. ${ }^{8}$

Usaha kecil dan rumah tangga memiliki misi yang sangat bagus untuk memperbaiki perekonomian, karena dengan adanya industri ini ialah dapat dan mampu untuk mewujudkan meningkatnya pendapatan masyarakat, antara lain dengan cara; 1) pembangunan yang merata, 2) luasnyalapangan pekerjaan dan kesempatan dalam usaha, 3) melestarikan serta mengembangkan kerajinan seni budaya tradisional dan meningkatkan penghasilan. ${ }^{9}$

Salah satu potensi nyata yang dapat menunjang pembangunan ekonomi ialah home indusry, karena dengan adanya home industrytenaga kerja menjadi terserap, dapat menghasilkan barang ataupun jasa dalam tingkatan harga yang dapat dijangkau oleh rakyat yang penghasilan rendah dan mendongkrak perekonomian daerahnya.Karena peranannya inilah diperlukan adanya suatu usaha agar usaha ini terus berkembang dan maju. ${ }^{10}$

Secara umum para pelaku home industry merupakan keluarga itu sendiri, dengan merekrut masyarakat disekitar untuk menjadi pekerja dalam usahanya, meskipun hanya termasuk skala kecil maka dari itu kegiatan ini secara langsung sudah membantu pemerintah untuk mengurangi angka pengangguran serta menurunnya jumlah penduduk miskin karena terbukanya lapangan pekerjaan bagi saudara atau tetangga sekitar.

Terserapnya para karyawan disekitar usaha membuat komunikasi antara pemilik usaha dengan karyawan menjadi sangat mudah.Hal ini

${ }^{7}$ Moh. Idil Ghufron dan Inas Fahmiyah, Konsep Waralaba Perspektif Ekonomi Islam, Amwaluna: Jurnal Ekonomi dan Keuangan Syariah, vol. 3 No. 1 Januari 2019, (Bandung: Universitas Islam Bandung 2019), h. 133

${ }^{8}$ Riski Ananda, Peran Home Industry Dalam Meningkatkan Ekonomi Keluarga, JPM FISIP, Vol. 3 No. 2 Oktober 2016, (Jawa Timur: Universitas Airlangga 2016), h. 3

${ }^{9}$ Muhammad Sumarno, Tingkat Adopsi Inovasi Teknologi Pengusaha Sentra Industri Kecil Kerajinan Gerabah Kasongan Kabupaten Bantul, Jurnal Manajemen dan Kewirausahaan, Vol. 12 No.1 Maret 2010, (Jawa Timur: Universitas Kristen Petra 2010), h.1

10 Rina Irawati, Pengaruh Pelatihan dan Pembinaan Terhadap Pengembangan Usaha Kecil, Jurnal JIBEKA, Vol. 12 No. 1 Tahun 2018, (Jawa Timur: LPPM Sekolah Tinggi Ilmu Ekonomi Asia Malang 2018), h.74 
diharapakan dapat menghasilkan etoskerja yang tinggi, dikarenakan dari setiap individu merasa bahwa usaha ini milik kita bersama sebagai suatu keluarga, sehingga timbul rasa tanggung jawab bersama untuk membuat perusahaan menjadi meningkat.

Ada beberapa alasan kuat yang menjadikan keberadaan home industry banyak segi positifnya; 1) tempat usaha lebih dominan berada di pedesaan, sehingga jika dengan keadaan yang terjadi sekarang bahwa banyak lahan pertanian yang semakin berkurang, sedangkan pekerjaan orang-orang desa mayoritas adalah sebagai petani, maka dengan adanya home industry dipedesaan dapat menyerap tenaga kerja, 2) bahan baku yang diproduksi dalam home industry bersumber di lingkungan sekitar, hal ini dapat meminimalisir biaya produksi dan 3) dengan relative rendahnya tingkat pendapatan yang didapat masyarakat serta harga barang yang murah meriah menjadi peluang bertahannya usaha. ${ }^{11}$

Undang-Undang No. 20 Tahun 2008 Pasal 1 tentang usaha mikro, kecil dan menengah diterangkan bawasanya usaha mikro merupakan usaha ekonomi yang menguntungkan, yang mandiri dalam artian berdiri sendiri serta dilakukan oleh individual ataupun badan usaha yang tidak termasuk anak perusahaan atau cabang usaha yang dimiliki, dikuasai, ataupun menjadi bagian baik langsung ataupun tidak langsung dari usaha menengah atau perusahaan besar yang sudah memenuhi karakteristik usaha kecil sesuai dengan Undang-Undang.

Sedangkan menurut Sumodiningrat usaha kecil mempunyai ciriciri utama sebagai berikut: 1) kedudukan yang sama antara pemilik beserta menejerial, 2) memakai tenaga kerja dari dalam, 3) mengandalkan modal sendiri, 4) sebagian bukan berbentuk badan hukum, serta 5) relative rendahnya tingkat usaha. Bank Indonesia juga memberikan ciri-ciri usaha kecil diantaranya; 1) dimiliki oleh perorangan atau keluarga, 2) memanfaatkan teknologi seadanya dan padat karya, 3) tingkat pendidikan serta keterampilannya rata-rata rendah, 4) sebagian belum berbadan hukum ataupun belum terdaftar secara resmi dan 5) tidak membayar pajak.

Sedangkan pemberdayaan adalah suatu strategi pembangunan yang dapat diimpleentasikan dan dapat dikembangkan untuk kegiatan pembangunan. ${ }^{12}$ Pemberdayaan merupakan suatu upaya dalam

${ }^{11}$ Fajriyah Astutik dan Retno Mustika D, Upaya Peningkatan Pendapatan Rumah Tangga Melalui Home Industry Gambir (Krupuk Kertas) di Dusun Dunengendak Desa Tlonjoraja Kecamatan Pasean Kabupaten Pamekasan, JUPE Jurnal Pendidikan Ekonomi, Vol. 1 No. 3 Tahun 2013, (Semarang: universitas Sebelas Maret 2013), h. 4

${ }^{12}$ Moch. Rochjadi Hafiluddin, et al., Strategi Pemberdayaan Usaha Mikro Kecil dan Menengah (UMKM) Berbasis Community Based Economic 
meningkatkan kemampuan yang dimiliki oleh seseorang ataupun kelompok sehingga dapat melakukan tugasnya sebagaimana tuntutan tugas kerjanya. Pemberdayaan disini adalah proses yang dilalui dengan berbagai usaha seperti halnya memberikan kekuasaan, kepercayaan, meningkatkan partisipasi sehingga semua orang dapat memahami pada pekerjaannya, pada akhirnya akan tercapai tujuan yang efektif dan efesien. ${ }^{13}$

Pemberdayaan usaha mikro kecil menengah merupakan salah satu upaya yang untuk menolong para pelaku maupun badan usaha yang sudah memenuhi syarat-syarat tertentu menurut Undang-Undang supaya lebih berdaya untuk meningkatkan dan mengoptimalkan sumber daya sehingga bisa meningkatkan kapasitas dan kemampuan untuk memanfaatkan potensi yang dimiliki. ${ }^{14}$

Terlaksanya pemberdayaan yang baik diperlukan untuk mengetahui dan memahami karakter atau masalah dalam usaha mikro sehingga mendapatkan solusi yang baik juga, berikut diantaranya: 1) modal, tenaga kerja dan pasar yang dimiliki masih terbilang kecil, 2) kebanyakan bertempat di pedesaan, kota-kota kecil atau pinggiran kota, 3) status usaha milik perorangan atau keluarga, 4) karyawan berasal dari lingkungan sosial, 5) sering dijadikan sebagai usaha sampingan dari kegiatan lain, 6) terbatasnya peralatan yang diguakan untuk mengelola usaha dan sederhananya administrasi,7) modal yang sangat terbatas sehingga bergantung pada modal dan lingkungan sendiri, 8) sering tidak memiliki ijin usaha dan tidak terpenuhinya beberapa persyaratan serta 9) kondisi lingkungan yang sangat berpengaruh pada strategi perusahan karena seringnya terjadi perubahan. ${ }^{15}$

Bank Indonesia menerapkan filosofi lima jari atau yang lebih dikenal dengan five finger philosophy untuk memberdayakan usaha mikro,

Development (Studi pada pelaku UMKM di Kecamatan Sukodono Kabupaten Sidoarjo), Wacana, Vol. 17 No. 2 Tahun 2014, (Jawa Timur: Universitas Brawijaya 2014), h. 72

${ }^{13}$ Ferry Duwi Kurniawan dan Luluk Fauziah, Pemberdayaan Usaha Mikro Kecil dan Menengah (UMKM)Dalam Penanggulangan Kemiskinan, JKMP Jurnal Kebijakan dan Manajemen Publik, Vol. 2 No. 2 September 2014, (Sidoarjo: Universitas Muhammadiyah Sidoarjo 2014), h. 168

${ }^{14}$ Desika Karinayah S, Pemberdayaan Usaha Mikro Kecil dan Menengah di Kabupaten Sidoarjo, JPM FISIP, Vol. 5 No. 2 Oktober 2018, (Jawa Timur: Universitas Airlangga 2018), h. 3

${ }^{15}$ Djawahir Hejazziey, Pemberdayaan Koperasi, Usaha Mikro, Kecil dan Menengah (UMKM) Melalui Lembaga Keuangan Syariah (LKS) Untuk Mengentaskan Kemiskinan dan Pengangguran, Al-Iqtishad, Vol. 1 No. 1 Januari 2009, (Jakarta: UIN Syarif Hidayatullah 2009), h. 38 
yang mana setiap jari itu mempunyai peran sendiri dan tidak bisa berdiri sendiri dan pasti akan lebih kuatjika saling menggenggam dan bersama:

a. Jari jempol, jari ini diumpamakan sebagai lembaga keuangan yang dapat memberikan pinjaman atau bahkan pembiayaan kepada pelaku usaha dan bisa juga sebagai agen pembagunan.

b. Jari telunjuk, mewakili pemerintah dan Bank Indonesia sebagai regulator sektor riil dan fiskal, mengurus perijinan usaha, menciptakan suasana yang kondusif dan sumber pembiayaan.

c. Jari tengah, sebagai perubahan untuk mempercepat sesuatu, dalam hal ini dengan mendukung perbankan dan usaha mikro seperti perusahaan yang menjamin pengkreditan.

d. Jari manis, sebagai fasilitator yang bertugas mendampingi usaha mikro, membantu usaha mikro untuk mendapatkan pembiayaan bank, menolong bank untuk memonitoring kredit dan tempat konsultasi untuk mengembangkan usaha mikro.

e. Jari kelingking, untuk mewakili usaha mikro sebagai pelaku usaha, membayar pajak dan merekrut tenaga kerja. ${ }^{16}$

Terdapat empat bidang dalam pemberdayaan usaha mikro, diantaranya: 1) Permodalan, permodalan disini ialah untuk mempermudah dalam mendapatkan pinjaman modal misalnya dana yang dipinjam dari lembaga keuangan syariah atau bahkan bantuan modal dari suatu perusahaan besar, 2) Pelatihan, pelatihan ini bertujuan untuk melayani masyarakat yang dijadikan wadah untuk memajukan suatu usaha yang dimiliki, 3) Pasar, dalam hal ini untuk memberikan kemudahan dalam pemasaran barang bagi para pelaku usaha dan 4) Meningkatkan kualitas produk, dalam hal ini menjadikan kunci utama dalam strategi pemberdayaan usaha mikro. ${ }^{17}$ Selain empat bidang diatas, dalampemberdayaan usaha mikro ada lima misi utama yang diterapkan yakni penyadaran, pengorganisasian, pendampingan, dukungan dalam hal teknis serta mengelola sistem. ${ }^{18}$

Usaha mikro termasuk usaha yang terbilang klasik karena cenderung masih menggunakan peralatan seadanya dan cenderung

\footnotetext{
${ }^{16}$ Kristina Sedyastuti, Analisis Pemberdayaan UMKM dan Peningkatan Daya Saing Dalam kancah Pasar Global, INOBIS: Jurnal Inovasi Bisnis dan Manajemen Indonesia, Vol. 2 No. 1 Desember 2018, (Jawa Timur: Pengurus Forum Inovasi Bisnis dan Manajemen Indonesia (INOBIS) 2018), h. 118

${ }^{17}$ Desika Karinayah S, Pemberdayaan Usaha Mikro....., h. 3

${ }^{18} \mathrm{Ni}$ Nyoman Sunariani, et cl., Pemberdayaan Usaha Mikro kecil dan Menengah (UMKM) Melalui Program Binaan di Provinsi Bali, Jurnal Ilmiah Manajemen dan Bisnis, Vol. 2 No. 1 Tahun 2017, (Bali: Fakultas Ekonomi dan Bisnis Universitas Pendidikan Nasional 2017), h. 226
} 
berorientasi di pasar lokal. Maka dari itu selalu upayakan untuk membuat strategi yang tepat dalam memberdayakan usaha mikro supaya kesejahteraan masyarakat meningkat.

Salah satu contohnya ialah Desa Kotaanyar Kecamatan Kotaanyar Kabupaten Probolinggo Jawa Timur. Kecamatan Kotaanyar sendiri berada di daerah Kabupaten Probolinggo lebih tepatnya dibagian tengah selatan dengan batas utara Kecamatan Paiton, batas timur Kabupaten Situbondo, batas selatan Kecamatan Pakuniran dan batas barat adalah Kecamatan Paiton. Sedangkanketinggian permukaan air laut berada diketinggian 200750 meter yang terdiri dari dataran rendah dan tinggi. Iklim di kawasan ini sama sebagaimana kecamatan lainnya yang ada di Kabupaten Probolinggo, yaitu beriklim tropis (musim penghujan dan kemarau). ${ }^{19}$

Badan Pusat Statistik (BPS) Probolinggo Kotaanyar tahun 2018 disebutkan bahwasanya Desa Kotaanyar termasuk tiga besar desa yang dipadati oleh penduduk, dengan4.163 penduduk dan 1483 rumah tangga dari 36.044 penduduk dan 12.918 rumah tangga. Dengan begitu sangat dibutuhkan pendongkrak ekonomi masyarakat Desa Kotaanyar salah satunya dengan berwirausaha/bisnis.

Desa Kotaanyar sendiri terdiri dari 9 RW dan 32 RT dengan 3 Dusun yang tersebar diantaranya; Dusun Krajan (blok Gazal), Dusun Koloran dan Dusun Buaran (blok Patemon). Mayoritas penduduk Desa Kotaanyar adalah bertani, penghasilan para petani tidak seberapa dan memerlukan waktu sekitar 3-4 bulan untuk panen. Dalam hal ini masyarakat Desa Kotaanyar berpikir keras bagaimana sekiranya income dalam keluarganya bertambah dan tidak hanya menunggu income dari hasil panen pertanian. Hal tersebut menjadikan salah satu penggerak terlahirnya kegiatan yang diciptakan oleh masayarakat disana ialah berwirausaha.

Mata pencaharaian merupakan sumber pokok perekonomian suatu masyarakat untuk memenuhi kebutuhan hidup sehari-hari. Dari hasil penelitian ini ditemukan bahwasanya sebagian besar masyarakat Kotaanyar mata pencahariannya adalah sebagai buruh tani akan tetapi khusus di Dusun Gazal sendiri sebagian mereka adalah berdagang kripik singkong.

Usaha rumah tangga atau biasa disebut home industry yang dijalankan dan ditekuni oleh masyarakat diantaranya mengolah hasil alam daerahnya menjadi suatu produk. ${ }^{20}$ Home Industry menjadi pilihan masyarakat Kotaanyar, mereka mengelola hasil alam daerah sekitar yaitu ketela pohon/singkong (bahan mentah) menjadi kripik.Singkong merupakan produk pertanian yang sangat cocok dijadikan sebuah unit

${ }^{19}$ Tim Penyusun Badan Pusat Statistik Probolinggo Kotaanyar Dalam Angka 2018 ( BPS Probolinggo Kotaanyar dalam angka 2018), h. 1

${ }^{20}$ Dini Rochdiani, et al., Manajemen Usaha........, h.51 
bisnis atau usaha dikarenakan banyak manfaat yang didapatkan oleh komoditi tersebut dan bermanfaat melihat dari segi pangsa pasar juga cukup menggiurkan atas bahan baku singkong.

Dengan memanfaatkan potensi ekonomi lokal dapat menghadirkan daya tarik serta daya saing tersendiri juga berpeluang untuk menciptakan lapangan pekerjaan. Dengan mencari secara lebih detail usaha apa saja yang menjadi ekonomi unggulan dalam setiap desa, serta berbagai masalah yang harus dipecahkan didalamnya.

Pendapatan merupakan kenaikan aktiva atau penurunan kewajiban atau juga penggabungan dari keduanya dalam waktu yang dipilih pada penjelasan pendapatan yang berakibat dari investasi, perdagangan menaruh jasa maupun aktifitas lainnya bertujuan untuk mendapatkan keuntungan. ${ }^{21}$

Arus keuangan yang terus mengalir menurut global usaha terhadap warga dalam bentuk upah atau gaji, bunga, sewa serta keuntungan merupakan arti pendapatan warga yang dikemukakan oleh Rosyidi. ${ }^{22}$ Bahwa pendapatan seseorang terdiri dari sewa upah dan gaji, bunga, laba perusahaan bukan perseroan, dividen dan pembayaran transfer.Sedangkan Charles dan Walter mengemukakan bahwasanya pendapatan (revenue) adalah jumlah yang didapatkan oleh seseorang atau bahkan kelompok setelah mereka memberikan suatu barang atau jasa pada konsumen. ${ }^{23}$

Menurut Prathama Rahardja dan Manurung Mandala dalam bukunya yang berjudul Teori Ekonomi Makro membagi jenis-jenis pendapatan ialah: 1) Pendapatan ekonomi ialah pendapatan yang didapatkan oleh perorangan atau sekelompok yang difungsikan dalam terpenuhinya kebutuhan tanpa harus mengubah asset bersih lainnya, 2) Pendapatan uang merupakan beberapa uang yang dihasilkan oleh perorangan atau sekelompok dalam satu periode menjadi pertanda balas jasa atas produksi yang diberikan dan, 3) Pendapatan personal atau perorangan merupakan bagian berdasarkan pendapatan nasional yang

${ }^{21}$ Muhammad Syafi'I Antonio. Bank Syari'ah (Dari Teori ke Praktik), (Jakarta: Gema Insani, 2001), h. 204

${ }^{22}$ Femy M.G. Tulusan dan Very Y. Londa, Peningkatan Pendapatan Masyarakat Melalui Program Permberdayaan di Desa Lolah II Kecamatan Tombabiri Kabupaten Minahasa, Jurnal LPPM BidangEkoSosBudKum, Vol. 1 No. 1 Tahun 2014, (Sulawesi Utara: LPPM Universitas Sam Ratulangi 2014), h. 93

${ }^{23}$ Riski Amaliyah dan Rini Setyo Witiastuti, Analisis Faktor yang Mempengaruhi Tingkat Literasi Keuangan di Kalangan UMKM Kota Tegal, Management Analisys Journal, Vol. 4 No. 3 Tahun 2015, (Jawa Tengah: Universitas Negeri Semarang 2015), h. 254 
sebagai hak beberapa individu dalam perekonomian, yang diartikan sebagai balas jasa atas kontribusinya dalam proses produksi. ${ }^{24}$

Sedangkan dilihat dari segi cara memperoleh dibagi menjadi dua; 1) pendapatan kotor adalah pendapatan yang didapatkan sebelum dikurangi dengan biaya-biaya dan 2) pendapatan bersih adalah pendapatan yang didapatkan setelah dikurangi dengan baya-biaya. ${ }^{25}$

Diharapkan dengan keberadaan suatu usaha atau home industry disetiap daerah akan membawa perubahan pada kehidupan masyarakat sekitarnya. Perubahan terjadi akibat meningkatnya kegiatan ekonomi dan sosial dari masyarakat itu sendiri. Seperti contoh halnya masyarakat Kotaanyar dengan adanya usaha ini lapangan pekerjaan terbuka untuk penduduk setempat, sehingga reveneues (pendapatan) masyarakat Desa Kotaanyar bertambah dan secara otomatis dapat memberikan sumbangsih bagi pendapatan masyarakat. Agar terbangun pemerataan ekonomi masyarakat yang adil dan makmur sesuai dengan konsep ekonomi islam.

Dalam dunia ekonomi hal ini dapat dijadikan sebagai tolak ukur tingkat kemajuan perekonomian suatu daerah, dengan berdasarkan pada bertambahnya angka Produk Domestik Bruto (PDB) dalam mengetahui pendapatan perkapita. Bertambahnya lapangan pekerjaan dan munculnya usaha-usaha yang ada menjadikan suatu peluang terwujudnya hasil dari pertumbuhan. ${ }^{26}$

Hal ini membuat peneliti menjadi tertarik untuk melakukan penelitian dengan judul home industry sebagai strategi pemberdayaan usaha mikro dalam meningkatkan reveneues masyarakat.

\section{METODE PENELITIAN}

Penelitian ini menggunakan metode penelitian deskriptif kualitatif, yakni menggambarkan dan menjelaskan apa saja yang terdapat dilokasi penelitian. Sedangkan metode untuk menentukan lokasi penelitian menggunakan metode purposive area home industry (kripik gazal makmur Kotaanyar) Kotaanyar Probolinggo.Responden atau informan dalam penelitian ini menggunakan purposive sampling, jadi dalam industri ini peneliti menemukan terdapat 7 home industry yang terdapat di Dusun

${ }^{24}$ Pratama Rahardja dan Manurung Mandala, Teori Ekonomi Makro, (Jakarta : Fakultas Ekonomi Universitas Indonesia, 2001), h. 38

${ }^{25}$ M. Tohar, Membuka Usaha kecil, (Yogyakarta: Kanisius, 2003), h. 15

${ }^{26}$ Moh.Idil Ghufron dan Moch. Rahmadtullah, Peran Ekonomi Kreatif Sebagai Solusi Mengatasi Pengangguran, DERIVATIF: Jurnal Ilmiah FE-UMM, Vol. 13 No. 1 Tahun 2019, (Lampung: Universitas Muhammadiyah Metro 2019), h. 4 
Gazal Kotaanyar. Disini peneliti hanya mengambil 3 pengusaha kripik singkong gazal berdasarkan macam home industry yang terbagi menjadi 3 bagian (home industry besar, menengah atau sedang dan kecil) dengan indentitas informan sebagai berikut; 1) Ibu Anggi memulai usaha kripik singkong gazal makmur pada tahun 2005, 2) Ibu Bibin mulai usahanya ditahun 2007 dan, 3) Ibu Sugeng di tahun 2012. Data yang digunakan dan dikumpulkan berupa data primer (wawancara, observasi serta dokumentasi) dan data sekunder (data dari sumber referensi yang berkaitan dengan objek penelitian).

\section{HASIL PENELITIAN DAN PEMBAHASAN}

Home industry menjadi penyelamat bagi kehidupan masyarakat baik itu penyelamat keuangan maupun lapangan pekerjaan sehingga pendapatan masyarakat sekitar menjadi meningkat. Adapun objek dari penelitian ini ialah home industry kripik singkong gazal makmur Kotaanyar. Gazal makmur merupakan sebuah home industry cemilan kripik singkong, dengan proses penjualannya ialah mengerjakan barang pesanan konsumen dan membuat produk dengan brand sendiri.

Usaha ini disebut dengan usaha kripik singkong gazal makmur karena letak usahanya berada di Dusun Gazal Desa Kotaanyar Kabupaten Probolinggo, sedangkan nama makmur mempunyai arti sejahtera, karena didusun ini banyak yang mempunyai usaha kripik singkong. Untuk mengantisipasi terjadinya pertengkaran antara sesama pengusaha akhirnya semua pengusaha disebut kripik singkong gazal makmur, sehingga kampung ini lebih dikenal dengan kampung kripik.

Sebagaimana pemberdayaan usaha ini dibantu dan dibina oleh CSR PT. POMI, dalam hal ini para pelaku usaha diberikan hak untuk mengelola, menggunakan serta mengembangkan usahanya. Maka dari itu strategi pemberdayaan usaha yang digunakan ialah berbasis pada potensi masyarakat sekitar terutama pada pelaku usaha seperti; mengganti peralatan usaha dengan yang lebih canggih, mempermudah perijinan usaha, netto, exp, dan surat ijin P-IRT serta mebantu dalam memperluas jaringan pemasaran.

Home industry kripik singkong gazal makmur ini terdiri dari 7 (tujuh) home industry yang ada di Desa Kotaanyar, yaitu kripik singkong gazal makmur ibu Anggi berdiri pada tahun 2005, home industry ibu Pit berdiri pada tahun 2000, home industry ibu Abli tahun 1998, home industry ibu Bibin pada tahun 2007, home industry ibu Sugeng berdiri pada tahun 2012, home industry ibu Fatimah pada tahun 1998, dan home industry ibu Sami berdiri pada tahun 1998.

Dalam home industry ini singkong merupakan bahan pokok yang harus terus tersedia dengan baik, jika seperti itu maka produksi kripik ini 
akan berjalan dengan lancar, begitupun sebaliknya. Maka dari itu persediaan bahan baku harus betul-betul diperhatikan. Para pelaku home industry di Desa Kotaanyar ini diperoleh dari pasar-pasar terdekat seperti pasar paiton dan pasar kotaanyar sendiri, serta membeli atau memesan di area dataran tinggi seperti Tiris dan Ranon.

Beberapa tahun terakhir ini minat masyarakat akan mengkonsumsi singkong juga meningkat dan terus mengalami peningkatan dari tahun ketahunnya. Dari segi bisnis, berwirausaha singkong juga menguntungkan dikarenakan waktu panen yang relative singkat yakni 1-5 bulan, akan tetapi untuk menghasilkan kripik singkong yang bagus dibutuhkan singkong yang bagus juga.

Selain bahan baku, kesuksesan suatu usaha juga didukung oleh sumber daya manusia yang ada didalamnya. Tenaga kerja atau karyawan dalam usaha kripik singkong ini merupakan tenaga kerja yang sudah terampil dan terdiri dari ibu-ibu dan bapak-bapak yang rumahnya tidak jauh dari usaha ini (kerabat sendiri bahkan tetangga sekitar).

Mereka merasa sangat dibantu dengan keberadaan usaha kripik singkong gazal ini, meskipun dengan gaji yang lumayan untuk memenuhi kebutuhan hidup dan bagi ibu-ibu yang bekerja, mereka tidak terus menerus bergantung pada penghasilan suami, karena bagi mereka bekerja dan menghasilkan uang sendiri merupakan income yang baik dalam keuangan keluarganya. Sedangkan bagi para pekerja pria mereka merasa sangat terbantu dalam artian tidak hanya menunggu hasil panen untuk mempunyai pendapatan.

Home industry gazal makmur terbilang masih sangat sederhana, bukan hanya dari peralatan yang digunakan sangat sederhana, dari segi pemasaran juga sederhana, mereka menggunakan metode promosi dan door to door. Industri rumahan akan dapat berkembang secara cepat jika produk yang ditawarkan berkualitas, bernilai, bermanfaat dan faktor penunjang lainnya. Meskipun sangat sederhana namun penjualan kripik singkong gazal makmur sampai keluar kota (Surabaya) bahkan keluar Jawa seperti Kalimantan.

Melihat begitu banyaknya pesanan yang diterima oleh home industry gazal makmur ini, mereka menerapkan dua metode untuk mengatasinya yakni pertama, memproduksi kripik singkong dari awal (bahan metah) sampai terakhir (menjadi kripik), dan yang kedua membeli kripik singkong yang mentah didesa lain.

Home industry ini terbagi menjadi 3 bagian yaitu home industry berskala besar, home industry berskala menengah dan home industry bersakala kecil. 
a. Home industry bersakala besar

Home industry ini dimiliki oleh ibu Anggi (27 karyawan) dan ibu Pit (6 karyawan), karena mereka paling banyak dalam memproduksi singkong dan terbesar dari pada yang lainnya.

b. Home industry berskala menengah

Home industry ini ditempati oleh ibu Bibin (4 karyawan) karena dia berhasil memproduksi kripik yang lumayan banyak akan tetapi lebih dari pada ibu Anggi dan ibu Pit.

c. Home industry berskala kecil

Home industry ini dimiliki oleh ibu Sugeng (1 karyawan), ibu Fatima (1 karyawan), ibu Sami (1 karyawan) dan ibu Abli (1 karyawan), mereka memproduksi kripik singkong lebih sedikit dari pada yang lainnya karena faktor usia.

Sudah kita ketahui bersama bahwa faktor produksi sangat berkaitan dengan pendapatan. Semakin tinggi atau semakin banyak jumlah kripik yang diproduksi maka semakin meningkat jumlah pendapatan yang didapatkan oleh home industry ini. Produksi sendiri merupakan proses mengolah bahan atau barang dengan bahan lainnya untuk menghasilkan hal yang baru.

Jumlah produski yang dihasilkan oleh setiap home industry tidaklah sama menyangkut berbedanya bahan baku (singkong) yang diproduksi setiap harinya. Ibu Anggi sendiri dalam satu hari meghabiskan 4-5 kwintal singkong, sedangkan Ibu Bibin 1,5 - 2 kwintal dalam setiap hari, dan Ibu Sugeng tidak menentu, hal ini terjadi karena faktor usia dan sedikitnya permintaan.

Sedangkan untuk pendapatan yang diperoleh oleh home industry di Desa Kotaanyar ini bervariasi tergantung pada seberapa banyak produksi dalam setiap harinya, seperti pendapatan ibu Anggi yang setiap harinya bisa mencapai Rp. 4.000 .000 (pendapatan kotor) dan pengeluaran setiap harinya adalah Rp. 2.700.000. Ibu Bibin pendapatan kotornya dapat mencapai Rp. 1.500.000 dan dikurangi biaya pengeluaran sebesar Rp. 620.000 setiap harinya, dan Ibu Sugeng Rp. 1.000.000 dengan beban pengeluaran Rp. 420.000.

Dapat dikatakan bahwa peranan usaha di Kotaanyar ini berjalan dengan baik, adanya usaha ini membantu pemilik dan masyarakat sekitar dalam perekonomian. Salah satunya seperti bertambahnya penghasilan dan berkurangnya jumlah pengangguran karena terbukanya lapangan pekerjaan khusunya ibu-ibu rumah tangga.

Dalam berwirausaha pasti ada hambatan atau kendala yang dialami oleh semua pelaku usaha, begitu juga dengan home industry kripik singkong gazal ini, berikut diantaranya: 
1. Bahan baku

Singkong merupakan bahan baku yang harus tetap ada baik itu dimusim kemarau atau penghujan, dan biasanya singkong ini panen satu tahun sekali yakni dimusim kemarau. Tumbuhan ini juga dapat dijumpai di perkebunan dan pegunungan, hal ini dapat memungkinkan untuk terkena hama dan sering dirusak oleh babi hutan.

2. Cuaca yang tidak stabil

Cuaca juga termasuk point penting dalam usaha ini, untuk memproduksi kripik singkong di Gazal Kotaanyar, berdasarkan wawancarayang dilaksanakan pada tanggal 15 Oktober2019, faktor cuaca sangat mempengaruhi pembuatan kripik. Kurangnya panas matahari dapat memperlambat dalam pembuatan kripik singkong, jika singkong kurang kering dalam artian keringnya tidak sempurna maka kualitas kripik singkong akan jelek.

\section{KESIMPULAN}

Melihat dari hasil penelitian ini, peneliti dapat menyimpulkan bahwasanya home industry yang ada di Dusun Gazal Kotaanyar Kecamatan Kotaanyar sangat membantu dalam peningkatan keuangan/pendapatan masyarakat baik bagi pemilik usaha maupun karyawan, juga dapat dijadikan suatu strategi dalam memberdayakan usaha mikro. Home industry dusun Gazal terbagi dalam 3 bagian ialah: Home industry skala besar yang terdiri dari ibu Anggi dengan pendapatan kotor setiap harinya adalah Rp.4.000.000 dan pendapatan bersihnya senilai Rp. 1.300 .000 dengan jumlah tenaga kerja 27 orang, kemudian home industry kripik singkong skala menengah yang terdiri dari ibu Bibin dengan pendapatan kotor setiap harinya adalah Rp.1.500.000 dan pendapatan bersihRp. 880.000 jumlah tenaga kerjanya adalah 4 orang, dan terakhir home industry skala kecil yang terdiri dari ibu Sugeng dengan pendapatan kotor setiap harinya adalah Rp. 1.000.000 dengan pendapatan bersih Rp.580.000 dan jumlah tenaga kerjanya adalah 1 orang.Setelah dilaksanakannya penelitian di home industry kripik singkong gazal Kotaanyar, berdasarkan observasi, analisis dan wawancara yang sudah dilakukan maka terdapat beberapa saran terkait home industry.Pertama, bagi home industry sendiri sebaiknya lebih meningkatkan metode pemasaran, seperti halnya media online mengingat metode yang masih digunakan selama ini adalah promosi dan door to door. Dan mungkin untuk kemajuan home industry kedepannya diperlukan adanya kerja sama antar sesamahome industry. Kedua, bagi pemerintah sebaiknya lebih memperhatikan para pelaku home industry, 
Achmad Fawaid \& Erwin Fatmala: Home Industri Sebagai Pemberdayaan Usaha Mikro Dalam Meningkatkan Financial Revenues Masyarakat

menjaga kestabilan home industry, dan mengadakan seminar terhadap para pelaku usaha untuk lebih berkembang.

\section{DAFTAR PUSTAKA}

Amaliyah, Riski dan Rini Setyo Witiastuti, Analisis Faktor yang Mempengaruhi Tingkat Literasi Keuangan di Kalangan UMKM Kota Tegal, Management Analisys Journal, Vol. 4 No. 3 Tahun 2015, Jawa Tengah: Universitas Negeri Semarang, 2015

Ananda, Amin Dwi dan Dwi Susilowati, Pengembangan Usaha Mikro Kecil dan Menengah (UMKM)Berbasis Industry Kreatif di Kota Malang, Jurnal Ilmu Ekonomi, Vol. 10 No. 10 Tahun 2017, Malang: Universitas Muhammadiyah Malang, 2017

Ananda, Riski, Peran Home Industry Dalam Meningkatkan Ekonomi Keluarga, JPM FISIP, Vol. 3 No. 2 Oktober 2016, Jawa Timur: Universitas Airlangga, 2016

Antonio, Muhammad Syafi'I, Bank Syariah (Dari Teorik Praktik), (Jakarta: Gema Insani, 2001)

Ariani dan Mohammad Nur Utomo, Kajian Strategi Pengembangan Usaha Mikro Kecil dan Mengengah (UMKM) di Kota Tarakan, Jurnal Organisasi dan Manajemen, Vol. 13 No. 2 Sepetember 2017, Tanggerang Selatan: LPPM Universitas Terbuka, 2017

Astutik, Fajriyah dan Retno Mustika D, Upaya Peningkatan Pendapatan Rumah Tangga Melalui Home Industry Gambir (Krupuk Kertas) di Dusun Dunengendak Desa Tlonjoraja Kecamatan Pasean Kabupaten Pamekasan, JUPE Jurnal Pendidikan Ekonomi, Vol. 1 No. 3 Tahun 2013, Semarang: Universitas Sebelas Maret, 2013

BPS Kabupaten Probolinggo, Kecamatan Kotaanyar Dalam Angka 2018. Probolinggo: CV. Azka Putra Pranama, 2018

Dini Rochdiani, et al., Manajemen Usaha Home Industry Desa Sindangsari Kecamatan Sukasari Kabupaten Sumedang, Jurnal Aplikasi Iptek Untuk Masyarakat, Vol. 7 No. 1 Maret 2018, Jawa Barat: Direktorat Sumber Daya Akademik Universitas Padjadjaran, 2018

Ghufron, Moh. Idil dan Inas Fahmiyah, Konsep Waralaba Perspektif Ekonomi Islam, Amwaluna: Jurnal Ekonomi dan Keuangan Syariah, vol. 3 No. 1 Januari 2019, Bandung: Universitas Islam Bandung, 2019

Ghufron, Moh. Idil dan Moch. Rahmadtullah, Peran Ekonomi Kreatif Sebagai Solusi Mengatasi Pengangguran, Jurnal Ilmiah FE-UMM, Vol. 13 No. 1 Tahun 2019, Lampung: Universitas Muhammadiyah Metro, 2019

Hejazziey, Djawahir, Pemberdayaan Koperasi, Usaha Mikro, Kecil dan Menengah (UMKM) Melalui Lembaga Keuangan Syariah (LKS) 
Achmad Fawaid \& Erwin Fatmala: Home Industri Sebagai Pemberdayaan Usaha Mikro Dalam Meningkatkan Financial Revenues Masyarakat

Untuk Mengentaskan Kemiskinan dan Pengangguran, Al-Iqtishad, Vol. 1 No. 1 Januari 2009, Jakarta: UIN Syarif Hidayatullah, 2009

Irawati, Rina, Pengaruh Pelatihan dan Pembinaan Terhadap Pengembangan Usaha Kecil, Jurnal JIBEKA, Vol. 12 No. 1 Tahun 2018, Jawa Timur: LPPM Sekolah Tinggi Ilmu Ekonomi Asia Malang, 2018

Kurniawan, Ferry Duwi dan Luluk Fauziah, Pemberdayaan Usaha Mikro Kecil dan Menengah (UMKM)Dalam Penanggulangan Kemiskinan, JKMP Jurnal Kebijakan dan Manajemen Publik, Vol. 2 No. 2 September 2014, Sidoarjo: Universitas Muhammadiyah Sidoarjo, 2014

Lutfiyah. "Pengaruh Pertumbuhan Ekonomi dan Usaha Mikro Kecil Menengah (UMKM) Terhadap Pendapatan Asli Daerah (PAD) di Kabupaten Bangkalan".Jurnal Pendidikan dan Ekonomi.Vol.4. No. 2. Tahun 2016.

Moch. Rochjadi Hafiluddin, et al., Strategi Pemberdayaan Usaha Mikro Kecil dan Menengah (UMKM) Berbasis Community Based Economic Development (Studi pada pelaku UMKM di Kecamatan Sukodono Kabupaten Sidoarjo), Wacana, Vol. 17 No. 2 Tahun 2014, Jawa Timur: Universitas Brawijaya, 2014

Ni Nyoman Sunariani, et al., Pemberdayaan Usaha Mikro kecil dan Menengah (UMKM) Melalui Program Binaan di Provinsi Bali, Jurnal Ilmiah Manajemen dan Bisnis, Vol. 2 No. 1 Tahun 2017, Bali: Fakultas Ekonomi dan Bisnis Universitas Pendidikan Nasional, 2017 Rahardja, Pratama dan Manurung Mandala, Teori Ekonomi Makro, (Jakarta: Fakultas EkonomiUniversitas Indonesia, 2001)

S, Desika Karinayah, Pemberdayaan Usaha Mikro Kecil dan Menengah di Kabupaten Sidoarjo, JPM FISIP, Vol. 5 No. 2 Oktober 2018, Jawa Timur: Universitas Airlangga, 2018

Sedyastuti, Kristina, Analisis Pemberdayaan UMKM dan Peningkatan

Daya Saing Dalam kancah Pasar Global, INOBIS: Jurnal Inovasi Bisnis dan Manajemen Indonesia, Vol. 2 No. 1 Desember 2018, Jawa Timur: Pengurus Forum Inovasi Bisnis dan Manajemen Indonesia (INOBIS), 2018

Sumarno, Muhammad, Tingkat Adopsi Inovasi Teknologi Pengusaha Sentra Industri Kecil Kerajinan Gerabah Kasongan Kabupaten Bantul, Jurnal Manajemen dan Kewirausahaan, Vol. 12 No.1 Maret 2010, Jawa Timur: Universitas Kristen Petra, 2010

Tohar, M, Membuka Usaha kecil, (Yogyakarta: Kanisius, 2003)

Tulusan, Femy M.G. dan Very Y. Londa, Peningkatan Pendapatan Masyarakat Melalui Program Permberdayaan di Desa Lolah II Kecamatan Tombabiri Kabupaten Minahasa, Jurnal LPPM 
Achmad Fawaid \& Erwin Fatmala: Home Industri Sebagai Pemberdayaan Usaha Mikro Dalam Meningkatkan Financial Revenues Masyarakat

BidangEkoSosBudKum, Vol. 1, No. 1 Tahun 2014, Sulawesi Utara: LPPM Universitas Sam Ratulangi, 2014

Zuhri, Saifuddin, Analisis Pengembangan Usaha Kecil Home Industry Sangkar Ayam Dalam Rangka Pengentasan Kemiskinan, Jurnal Manajemen Akuntansi, Vol. 2 No. 3 Desember 2013, Malang: Universitas Widyagama, 2013 
Achmad Fawaid \& Erwin Fatmala: Home Industri Sebagai Pemberdayaan Usaha Mikro Dalam Meningkatkan Financial Revenues Masyarakat 